\title{
Effects of Karenia brevis harmful algal blooms on nearshore fish communities in southwest Florida
}

\author{
Damon P. Gannon ${ }^{1,4, *}$, Elizabeth J. Berens McCabe ${ }^{1,2}$, Sandra A. Camilleri ${ }^{1,2}$, \\ Janet G. Gannon ${ }^{1,2}$, Mary K. Brueggen ${ }^{1,3}$, Aaron A. Barleycorn ${ }^{2}$, Valeriy I. Palubok ${ }^{1}$, \\ Gary J. Kirkpatrick ${ }^{1}$, Randall S. Wells ${ }^{1,2}$ \\ ${ }^{1}$ Mote Marine Laboratory, 1600 Ken Thompson Parkway, Sarasota, Florida 34236, USA \\ ${ }^{2}$ Chicago Zoological Society, c/o Mote Marine Laboratory, 1600 Ken Thompson Parkway, Sarasota, Florida 34236, USA \\ ${ }^{3}$ Division of Biological Sciences, University of Missouri-Columbia, Columbia, Missouri 65211, USA \\ ${ }^{4}$ Present address: Bowdoin Scientific Station, c/o Department of Biology, Bowdoin College, 6500 College Station, \\ Brunswick, Maine 04011, USA
}

\begin{abstract}
Blooms of the toxic alga Karenia brevis, commonly referred to as 'Florida red tides,' occur along Florida's west coast on a near-annual basis, causing massive fish kills. However, few quantitative data on the ecological effects of red tides on fish communities exist. We surveyed fish communities in 5 habitats within Sarasota Bay and the adjacent Gulf of Mexico during the summers of 2004 to 2007 using a purse seine. We collected contemporaneous data on fish densities, fish species composition, $K$. brevis cell densities, water temperature, salinity, dissolved oxygen, and turbidity. Fish density (catch per unit effort [CPUE]) and species richness were significantly lower in all habitats during red tides. Shannon-Wiener diversity indices were significantly lower in 4 of 5 habitats during red tides. Classification and regression tree analysis showed significant negative relationships between $K$. brevis density and non-clupeid CPUE, and between $K$. brevis density and species richness. Fish community structure differed significantly between red tide and non-red tide conditions. Canonical correspondence analysis showed that of all the environmental factors investigated, $K$. brevis density had the greatest influence on community structure. Most trophic guilds were negatively associated with $K$. brevis density, whereas the guild that included clupeids was positively associated with $K$. brevis density. Florida's fish kill database showed that $96 \%$ of local fish kills during 2003 to 2007 occurred during red tides. We concluded that red tides caused the observed changes in fish abundance and community structure. Harmful algal blooms occur throughout the world and may play an important, yet little understood, role in regulating fish communities.
\end{abstract}

KEY WORDS: Red tide $\cdot$ Karenia brevis $\cdot$ Fishes $\cdot$ Community $\cdot$ Biodiversity $\cdot$ Harmful algal bloom Resale or republication not permitted without written consent of the publisher

\section{INTRODUCTION}

Over the past several decades, harmful algal blooms (HABs) have become more frequent and widespread (Anderson 1989, Smayda 1990, Hallegraeff 1993, Van Dolah 2000). Causes of the increased bloom frequency and duration are currently unknown but climate change and alterations in nutrient dynamics may play a role (Van Dolah 2000). HABs caused by the dinoflagellate Karenia brevis, commonly called 'Florida red tides,' occur frequently along Florida's west coast
(Brand \& Compton 2007). K. brevis produces brevetoxins $(\mathrm{PbTx})$, a suite of neurotoxins that cause acute neurological symptoms including death in fishes (Baden \& Mende 1982, reviewed by Landsberg 2002, Naar et al. 2007). K. brevis blooms can also increase biochemical oxygen demand, resulting in hypoxia or anoxia (Smith 1975, 1979, Hu et al. 2006). Severe K. brevis red tides, therefore, result in episodes of high mortality among vertebrates, most notably fishes (Gunter et al. 1948, Smith 1975, 1979, reviewed by Landsberg 2002). 
Much research effort has focused on the formation and persistence of Karenia brevis blooms and on the health effects of PbTx on individual animals, but little attention has been paid to the population- or community-level effects of Florida red tides on upper trophiclevel organisms. Warlen et al. (1998) compared the community of ocean-spawned, estuarine-dependent larval fishes recruiting to a North Carolina estuary during a $K$. brevis red-tide event to the larval community recruiting during non-red tide periods. Recruitment during the red-tide event was not particularly low, although 2 of the 9 species investigated experienced their $8 \mathrm{yr}$ minima during this period (Warlen et al. 1998). Smith $(1975,1979)$ documented the extirpation and subsequent recolonization of the ecological communities on offshore patch reefs in the Gulf of Mexico off central Florida following a severe red-tide event, and hypothesized that red tide was one of the major factors regulating the structure of reef communities in the Gulf. To our knowledge, the Smith papers (1975, 1979) are the only published works on the ecological effects of Florida red tides on post-larval fish communities. Lack of information on how HABs affect ecological communities has been identified as a significant problem for marine resource managers (HARRNESS 2005).

Estuaries are highly productive habitats (Allen 1982) that are both ecologically and economically important (Deegan \& Thompson 1985, Houde \& Rutherford 1993, Hoss \& Engel 1996, Heck et al. 2003). Estuaries on Florida's Gulf Coast are frequently subjected to Karenia brevis red tides (Brand \& Compton 2007). We documented changes in the fish communities of 5 discrete habitats located in the vicinity of Sarasota Bay, Florida (4 habitats within the estuary and 1 in nearshore Gulf of Mexico waters, adjacent to Sarasota Bay) that occurred during red tides. We tested 3 hypotheses:

$H_{1}$ : Mortality and/or dispersal associated with Florida red tides cause significant changes in fish abundance.

$\mathrm{H}_{2}$ : Florida red tides are associated with changes in species diversity of fishes.

$H_{3}$ : Florida red tides are associated with changes in community structure (caused by differing susceptibility to brevetoxin, differing rates or mechanisms of population recovery, changes in the source of primary production, changes in food availability, and/or changes in risk of predation).

\section{MATERIALS AND METHODS}

Study area and general approach. We conducted concurrent surveys of (1) Karenia brevis cell density (summers, 2005 to 2007), (2) density and distribution of living fishes (summers, 2004 to 2007), and (3) water quality (temperature, salinity, dissolved oxygen, and turbidity; summers, 2005 to 2007) aboard the $9 \mathrm{~m}$ RV 'Flip', using a stratified random sampling design (Fig. 1). The study area encompassed waters from Passage Key Inlet $\left(27.5528^{\circ} \mathrm{N}, 82.7423^{\circ} \mathrm{W}\right)$ southward to Phillippi Creek $\left(27.27096^{\circ} \mathrm{N}, 82.53757^{\circ} \mathrm{W}\right)$ on Florida's southwest coast, including the waters of the Gulf of Mexico (up to $4 \mathrm{~m}$ deep); Anna Maria Sound; and Sarasota, Palma Sola, and Roberts Bays (Fig. 2). Sampling aboard RV 'Flip' occurred from $1 \mathrm{~h}$ after sunrise to $1 \mathrm{~h}$ before sunset to minimize sampling biases associated with light levels. Five discrete habitat strata within the study area were investigated, 4 inside the estuary and 1 in the Gulf of Mexico: (1) estuarine seagrass beds (primarily Thalassia testudinum but also Syringodium filiforme and Halodule wrightii) with water depths 0.5 to $2.5 \mathrm{~m}$, (2) estuarine mangrove fringe $(0$ to $25 \mathrm{~m}$ from prop roots of Rhizophora mangle), (3) open bay (estuarine waters of Sarasota Bay proper, $>400 \mathrm{~m}$ from shore, water depth 2.5 to $4.0 \mathrm{~m}$, with unvegetated bottom), (4) sandflat (estuarine waters, 0.5 to $2.5 \mathrm{~m}$ deep with unvegetated bottom), and (5) nearshore Gulf of Mexico (1.0 to $4.0 \mathrm{~m}$ depth). Sampling effort was distributed uniformly across all 5 habitat strata. These 5 habitats were delineated in a geographic information sys-
Fig. 1. Sampling chronology (winter [W], spring [Sp], summer [Su], and fall [F] of 2003 to 2007) for study of the effects of Karenia brevis on the fish communities of Sarasota Bay and adjacent waters. FWRI: State of Florida's Fish and Wildlife Research Institute 


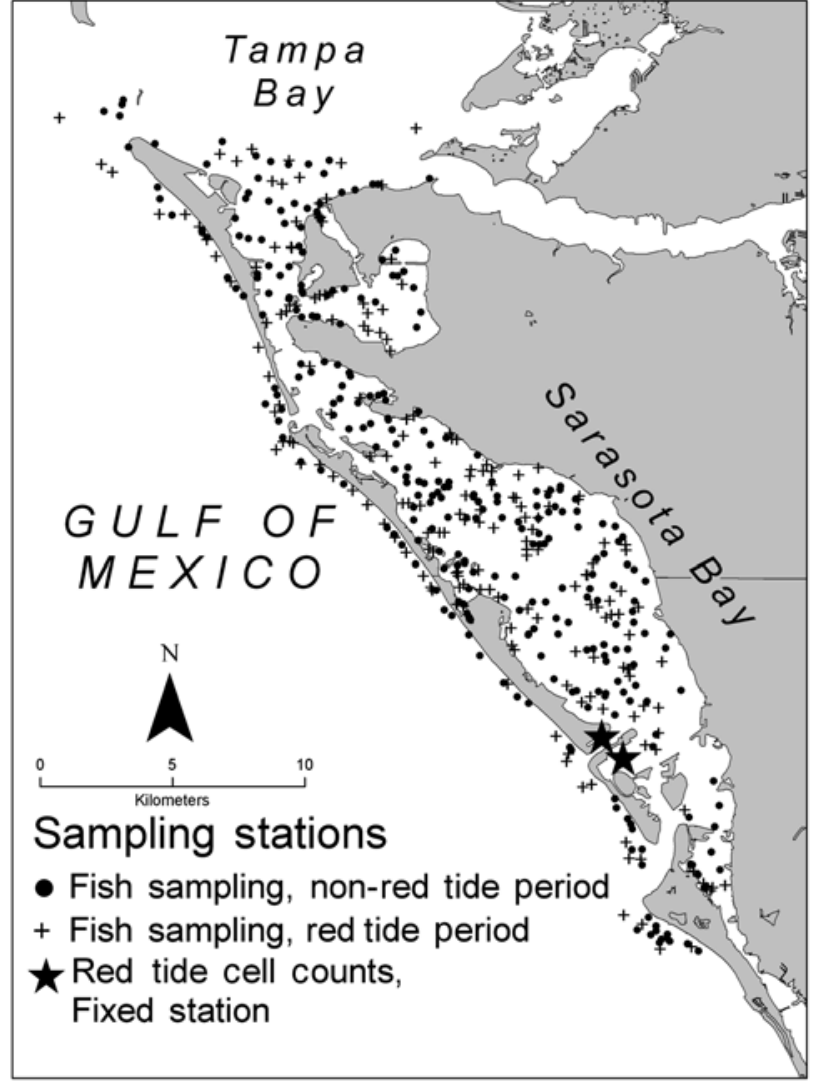

Fig. 2. Study area showing the locations of 477 purse-seine deployments (292 during non-red tide periods and 185 during red-tide periods) from the summers of 2004 to 2007 and of daily Karenia brevis monitoring stations in New Pass and City Island Grass Flats

tem (GIS; ArcGIS 8.0) using field notes, aerial photographs, and ancillary shapefiles such as seagrass coverages produced by the Southwest Florida Water Management District. A sampling grid with $200 \times$ $200 \mathrm{~m}$ resolution was overlaid on a GIS coverage of the study area (6142 grid cells in total). Potential sampling sites were located at the centroids of each grid cell, and grid cells to be sampled were chosen at random. Sampling sites were located in the field with a Wide Area Augmentation System (WAAS)-enabled GPS unit (Garmin GPS Map 162), and the actual habitat type was verified in the field prior to sampling. In addition to the stratified random sampling scheme, we collected supplemental data on $K$. brevis cell densities daily at 2 fixed sampling stations (year-round, 2003 to 2007) and analyzed data on the occurrence and severity of fish kills that were compiled by the State of Florida (yearround, 2003 to 2007; Fig. 1).

Karenia brevis cell counts. We used 2 independent sampling schemes to assess spatial and temporal trends in $K$. brevis abundance. We sampled at (1) every station visited by RV 'Flip' as part of the stratified random sampling scheme during the summers of 2005 to 2007 (June 1 to September 30) and (2) at 2 fixed monitoring sites (New Pass channel and City Island Seagrass Flats; Fig. 2) year-round on weekdays from January 1, 2003 to December 31, 2007. K. brevis sampling aboard RV 'Flip' was intended to cover the entire spatial extent of the study area and to investigate the relationship between $K$. brevis densities and fish abundance at fine temporal and spatial scales by obtaining 'snapshots' at particular locations. $K$. brevis sampling at the 2 fixed stations was intended to investigate temporal trends over the $5 \mathrm{yr}$ sampling period and to determine whether red tides occurred between our intense summer sampling seasons.

Water sample collection and cell-counting procedures for both sampling schemes followed the protocols of Lund et al. (1958), Sournia (1978), and Sellner et al. (2003). Surface water samples were collected in $20 \mathrm{ml}$ glass scintillation vials. Water samples collected by the purse-seine boat at the random stations were taken immediately prior to fish sampling. All water samples were preserved using Utermöhl's solution (Utermöhl 1958, Guillard 1973) at the time of collection and stored in darkness at room temperature until they were processed in the laboratory (usually within $5 \mathrm{~d}$ ). Cells were resuspended in the vials by gentle agitation and a $1 \mathrm{ml}$ subsample was placed in the well of a microscope slide. The number of Karenia brevis cells in the $1 \mathrm{ml}$ subsample was counted using an inverted Olympus CK40 microscope, and then it was multiplied by 1000 to obtain an estimate of the number of cells $\mathrm{l}^{-1}$. For samples with high concentrations of $K$. brevis (approximately $>10^{6}$ cells $\mathrm{l}^{-1}$ ), 1:10 serial dilutions were performed using filtered water of the same salinity as that in the sample (to avoid damaging the unarmored $K$. brevis cells). For very highly concentrated samples (approximately $>10^{7}$ cells $\mathrm{l}^{-1}$ ), an Olympus BH-2 binocular phase-contrast microscope with Fuchs-Rosenthal hemocytometer (Hausser Scientific) covering glass divided with grid lines was also used. Tomas (1997) was used as a guide to identify $K$. brevis cells.

Fish abundance, diversity, and community structure. To assess the relative abundance of fishes at every randomly selected sampling station, we deployed a $183 \times 6.6 \mathrm{~m}$ purse seine net from RV 'Flip' following the general methods of Wessel \& Winner (2003). The net was symmetrical (no bunt) and had $2.5 \mathrm{~cm}$ diamond mesh made from No. 7 nylon twine. The cork line was $1.3 \mathrm{~cm}$ twisted polypropylene line with SB10 'can' floats spaced every $45 \mathrm{~cm}$. The footrope was a doubled, $39 \mathrm{~kg}$ lead core line. The $10.2 \mathrm{~cm}$ purse rings were attached to $91 \mathrm{~cm}$ of $9.5 \mathrm{~mm}$ braided polypropylene line, which were fastened to the footrope at $2.8 \mathrm{~m}$ intervals (65 purse rings in total). 
The lead tom weight weighed $68 \mathrm{~kg}$ and the purse line was $366 \mathrm{~m}$ of $18 \mathrm{~mm}, 12$-strand braided Polytron. This purse seine was used to enclose a cylinder of the water column from the benthos to the surface, thus capturing pelagic as well as benthic fishes, and was used in water depths between 0.5 and $4.0 \mathrm{~m}$ (Sarasota Bay's maximum depth). When deployed, the net enclosed an area of $2666 \mathrm{~m}^{2}$. All fishes and cephalopods captured were identified to species, measured, and counted. This sampling yielded measures of relative abundance for each species, which was expressed as catch per unit effort (CPUE), or the mean number of organisms caught during each standardized deployment of the net.

Water quality analyses. A YSI 85 multiprobe was used to measure temperature, salinity, and dissolved oxygen approximately $15 \mathrm{~cm}$ above the bottom at each of the randomly selected stations sampled by RV 'Flip' from June 1, 2005 to September 30, 2007. In addition, turbidity was measured with a $61 \mathrm{~cm}$ diameter Secchi disk at every station located within the 2 deep-water habitats (Gulf and open bay) from June 1, 2004 to September 30, 2007.

Fish kills. The State of Florida's Fish and Wildlife Research Institute maintains a statewide fish kill database (http://research.myfwc.com/fishkill/). Data on fish kills are reported to the database managers by the general public and opportunistically by state biologists working in the field. Thus the information recorded is largely anecdotal and qualitative in nature, but is useful for interpreting the other data that we collected.

As a rough indication of the acute mortality caused by red tide, we queried the database for all fish kills that occurred in the study area between January 1, 2003 and December 31, 2007. We quantified the total number of fish kills during each year from 2003 to 2007, as well as during red tide and non-red tide periods. Since the data were not collected using a standardized protocol, we simply summarized them without performing any statistical analyses. The database was accessed on January 5, 2008.

Data analyses. Sampling periods were designated as 'red tide' or 'non-red tide' based on Karenia brevis cell counts. We defined red-tide conditions as commencing at the time when $K$. brevis density anywhere within the study area exceeded $10^{5}$ cells $\mathrm{l}^{-1}$ and persisting for $30 \mathrm{~d}$ beyond the time at which cell counts dropped back down below $10^{5}$ cells $1^{-1}$. A threshold of $10^{5}$ cells $\mathrm{l}^{-1}$ was chosen because this value is thought to be the level at which fish kills begin to occur (Quick \& Henderson 1974, Landsberg \& Steidinger 1998). The $30 \mathrm{~d}$ lag was incorporated into the definition of what constitutes red-tide conditions because brevetoxins are known to persist in the food web for over a year follow- ing red tide events (Naar et al. 2007) and once the structure of the fish community has been perturbed by the toxic red tide, a return to the pre-red tide community composition would require immigration of adults/juveniles and/or larval recruitment. Depending on the seasonal timing of the red tide, larval recruitment might take up to a year to occur. Therefore, use of the $30 \mathrm{~d}$ lag period was a conservative approach that accounted for some the lingering effects of red tide, but it likely underestimated the duration of the disturbance.

From the purse-seine data, CPUE, species richness, and Shannon-Wiener diversity indices were calculated for each habitat during red tide and non-red tide conditions. For each habitat, total CPUEs for non-red tide periods were compared to those of red-tide periods using $t$-tests. Classification and regression tree (CART) analysis was used to explore relationships between a dependent variable (either CPUE or species richness) and 5 independent variables (water depth, water temperature, dissolved oxygen concentration, salinity, and Karenia brevis cell count) for each habitat. In the 2 deepest habitats (open bay and Gulf), turbidity was included as a sixth independent variable. The CART method tests the global null hypothesis of independence between the dependent variable and each of the environmental variables (Urban et al. 2002). Here we applied a CART analysis to determine whether there were any threshold values in water-quality parameters or in $K$. brevis cell counts associated with abrupt changes in fish abundance or diversity. We ran the CART analysis using the 'Party' library in the $\mathrm{R}$ software environment (version 2.6.1, available at www.Rproject.org; Hothorn et al. 2006). p-values were calculated using a quadratic test statistic.

Changes in diversity associated with the occurrence of red tide were assessed by the Shannon-Wiener diversity index (Shannon \& Weaver 1949) and by species richness (the number of species caught per standardized seine set). Differences between red tide and non-red tide periods regarding Shannon-Wiener diversity indices and species richness were assessed using 2-sample $t$-tests (Hutcheson 1970) that were run in SPSS (version 15).

To determine whether red tide was associated with a change in the composition of the fish community, we performed 1-way multivariate analyses of variance (MANOVAs) with fixed effects in Statistica (version 5.5, StatSoft). All fish captured were assigned to a guild based on their vertical distribution in the water column and their feeding habits: Guild 1, demersal herbivore; Guild 2, demersal invertivore; Guild 3, demersal omnivore; Guild 4, demersal piscivore; Guild 5, detritivore; Guild 6, pelagic filter feeder; Guild 7, pelagic invertivore; Guild 8, pelagic omnivore; and 
Guild 9, pelagic piscivore. Assignments to guilds were based on the literature, including Robins et al. (1999) and Hoese \& Moore (1998). Species included in each guild are listed in Appendix 1. The dependent variables used in the MANOVAs were the CPUEs for each of the 9 trophic guilds, and the independent variable was a binary indicating whether the sample was collected during red tide or non-red tide conditions.

We used canonical correspondence analysis (CCA) to investigate the relationship between community structure and environmental features, as well as the degree of similarity in guild composition of seine samples during red tide and non-red tide periods (ter Braak \& Verdonschot 1995, Guisan \& Zimmermann 2000, McCune \& Grace 2002). The potential homogenizing effect of guilds that were rare in a particular habitat during both sampling periods (red tide and non-red tide) were minimized by including only those guilds that were present in $>10 \%$ of seine sets in at least 1 sampling period (red tide or non-red tide period). Stations at which no fish were captured were also excluded from analysis. Fish assemblage data, calculated from the CPUEs of each guild, were used to calculate Bray-Curtis similarity matrices for each habitat. CCA results were displayed as triplots in which seine samples, guilds, and environmental features were plotted in 2-dimensional ordination space defined by CCA Axes 1 and 2. The association of environmental variables with the axes is represented by how parallel each variable's vector is to the axis. The distance between individual seine samples reflects their degree of similarity regarding guild composition. The distance between guilds on the triplot indicates their degree of similarity regarding the range of environmental conditions under which they were found. The plotted positions of individual seine samples relative to the environmental vectors are indicative of the environmental conditions at the time of sampling.
Likewise, the position of each guild relative to the environmental vectors indicates the environmental conditions under which the guild is normally found. CCA was performed using PC Ord (version 4.34, MjM Software).

For analyses in which samples could be categorized by red tide or non-red tide conditions (i.e. $t$-tests and MANOVAs), we were able to include all data from 2004 to 2007. For CART and CCA, which require a full suite of data (Karenia brevis, water-quality parameters, and fish abundance) for every sample, only data collected from 2005 to 2007 were included (see Fig. 1). Prior to analysis, CPUE and $K$. brevis cell count data were transformed using $\ln (x+1)$ for $t$-tests and MANOVAs, and using $\log (x+1)$ for CART and CCA.

\section{RESULTS}

\section{Karenia brevis cell counts}

Sampling effort is detailed in Table 1. There were 3 major red-tide blooms during the period from January 1, 2003 to December 31, 2007. Daily monitoring at the 2 fixed sampling stations in Sarasota Bay (City Island seagrass flats and New Pass) revealed Karenia brevis densities of $1 \times 10^{5}$ to $1.5 \times 10^{6}$ cells $^{-1}$ from April to September $2003,10^{5}$ to $10^{8}$ cells $1^{-1}$ from January to December 2005, and $10^{5}$ to $10^{7}$ cells $1^{-1}$ from August 2006 to January 2007. From mid-January 2007 to the end of the study period, $K$. brevis cell counts were $\leq 10^{4}$ cells $\mathrm{l}^{-1}$ at the 2 fixed stations (Fig. 3).

Karenia brevis densities measured in water samples taken at the randomly selected purse-seine sampling stations during 2005 to 2007 showed temporal and intensity patterns similar to those of the 2 fixed monitoring stations sampled daily: high cell counts during the entire 2005 sampling season and from mid-August

Table 1. Sampling effort of RV 'Flip' at randomly selected stations in the Sarasota Bay study area during the summers of 2004 to 2007 by year and red tide condition

\begin{tabular}{|c|c|c|c|c|c|c|c|}
\hline \multirow{2}{*}{ Parameter } & \multicolumn{4}{|c|}{ Year } & \multicolumn{2}{|c|}{ Red tide condition } & \multirow[t]{2}{*}{ Total } \\
\hline & 2004 & 2005 & 2006 & 2007 & Non-red tide & Red tide & \\
\hline No. of purse-seine sets & 73 & 125 & 133 & 146 & 292 & 185 & 477 \\
\hline Seagrass & 16 & 24 & 33 & 30 & 66 & 37 & 103 \\
\hline Mangrove & 13 & 26 & 25 & 28 & 55 & 37 & 92 \\
\hline Sandflat & 10 & 19 & 24 & 29 & 51 & 31 & 82 \\
\hline Open bay & 18 & 23 & 30 & 29 & 63 & 37 & 100 \\
\hline Gulf & 16 & 33 & 21 & 30 & 57 & 43 & 100 \\
\hline No. of species caught & 89 & 55 & 77 & 90 & 114 & 72 & 118 \\
\hline No. of individual fish caught & 25116 & 21528 & 77086 & 85032 & 152150 & 56612 & 208762 \\
\hline No. of water quality measurements made & 0 & 125 & 133 & 146 & 221 & 183 & 404 \\
\hline No. of Karenia brevis cell counts made & 0 & 77 & 129 & 138 & 207 & 137 & 344 \\
\hline
\end{tabular}



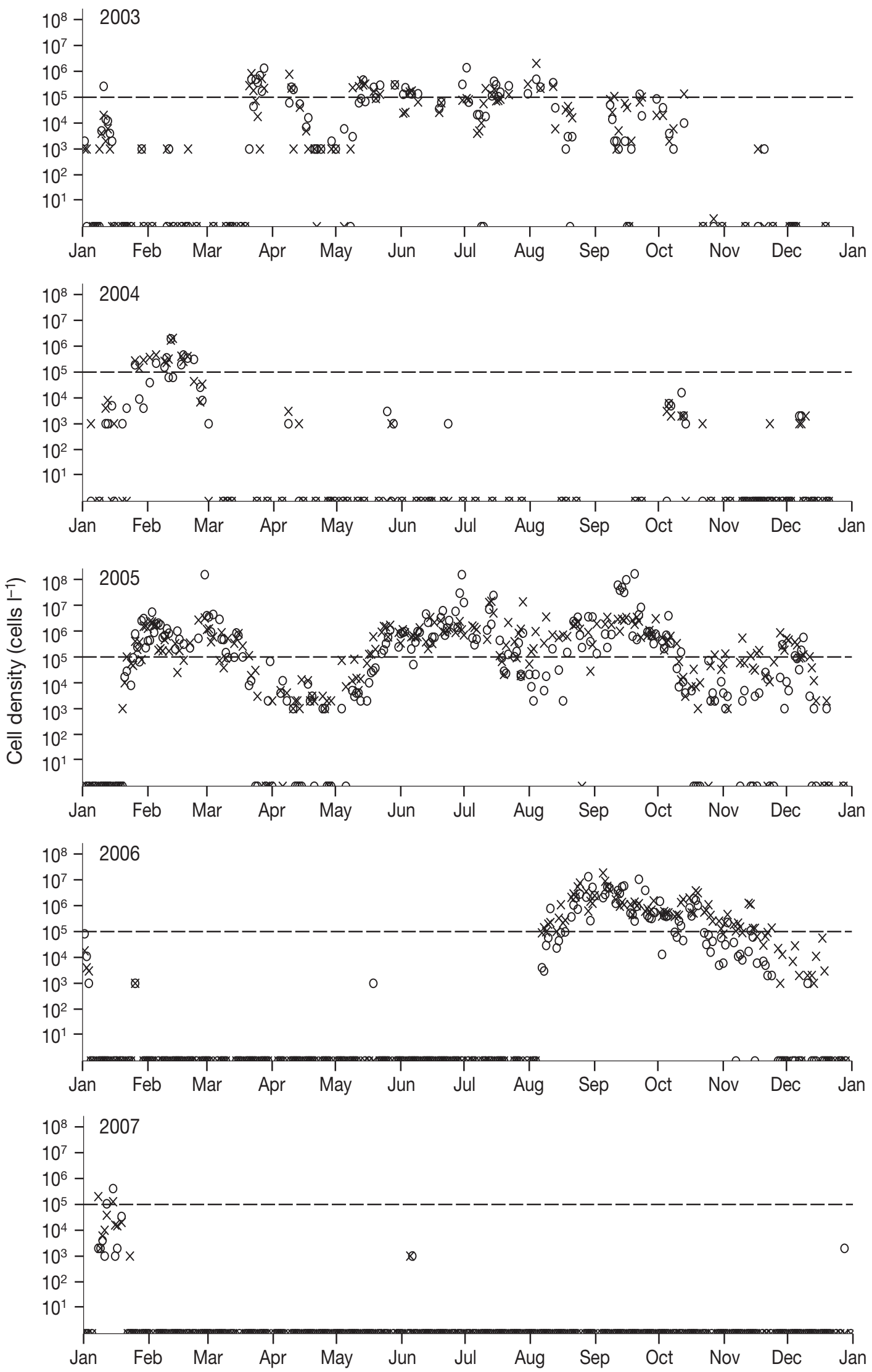

Fig. 3. Karenia brevis. Cell densities measured daily at the New Pass $(\times)$ and City Island Grass Flats (O) reference stations during

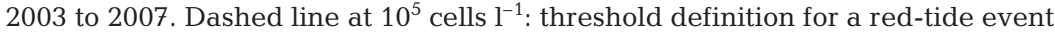




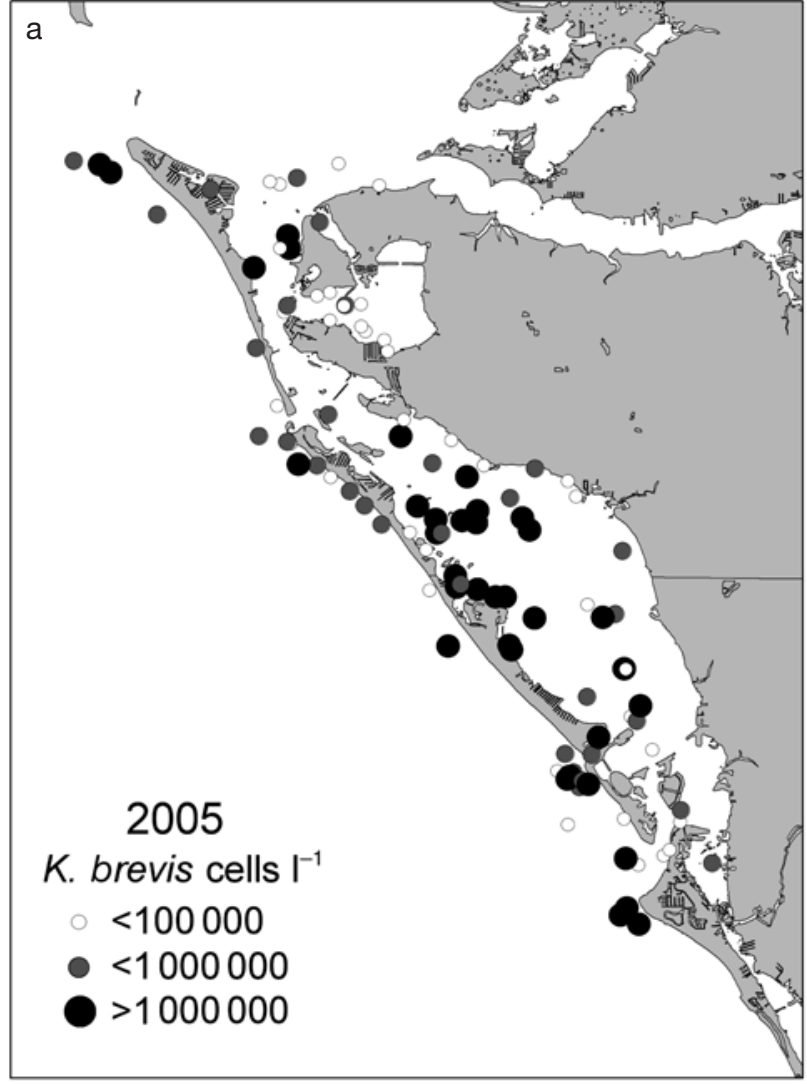

Fig. 4. Karenia brevis. Cell densities measured at each randomly selected fish sampling location during summer (a) 2005, (b) 2006, and (c) 2007

to the end of the sampling season in 2006, and low cell counts from June to August 2006 and during the entire 2007 sampling season (Fig. 4).

Based on the criteria outlined above $\left(>10^{5}\right.$ Karenia brevis cells $\mathrm{l}^{-1}$ anywhere in the study area on a particular day or within the previous $30 \mathrm{~d}$ ), the study area was considered to be under red-tide conditions for $49 \%$ of the days between January 1, 2003 and December 31, 2007 (Table 2, Figs. 3 \& 4). The year 2007 had the fewest days of red tide conditions $(11 \%)$ and 2005 had the most $(95 \%)$. For the period during which fish sampling occurred (summers of 2004 to 2007), the entire summer season of 2005 and August 10 to September 30, 2006 were designated as 'red-tide periods.' Mean \pm SD K. brevis cell counts at the randomly selected purse-seine stations were $1615761 \pm$ 7956 506) cells $l^{-1}$ during red tide and $0 \pm 0$ cells l$^{-1}$ during non-red tide periods. There were significant differences in cell counts among habitats during redtide periods, with the highest mean cell counts occurring in the Gulf and lowest in the sandflat habitat (Table $2 ; F_{4,132}=6.994, \mathrm{p}<0.01$ ).
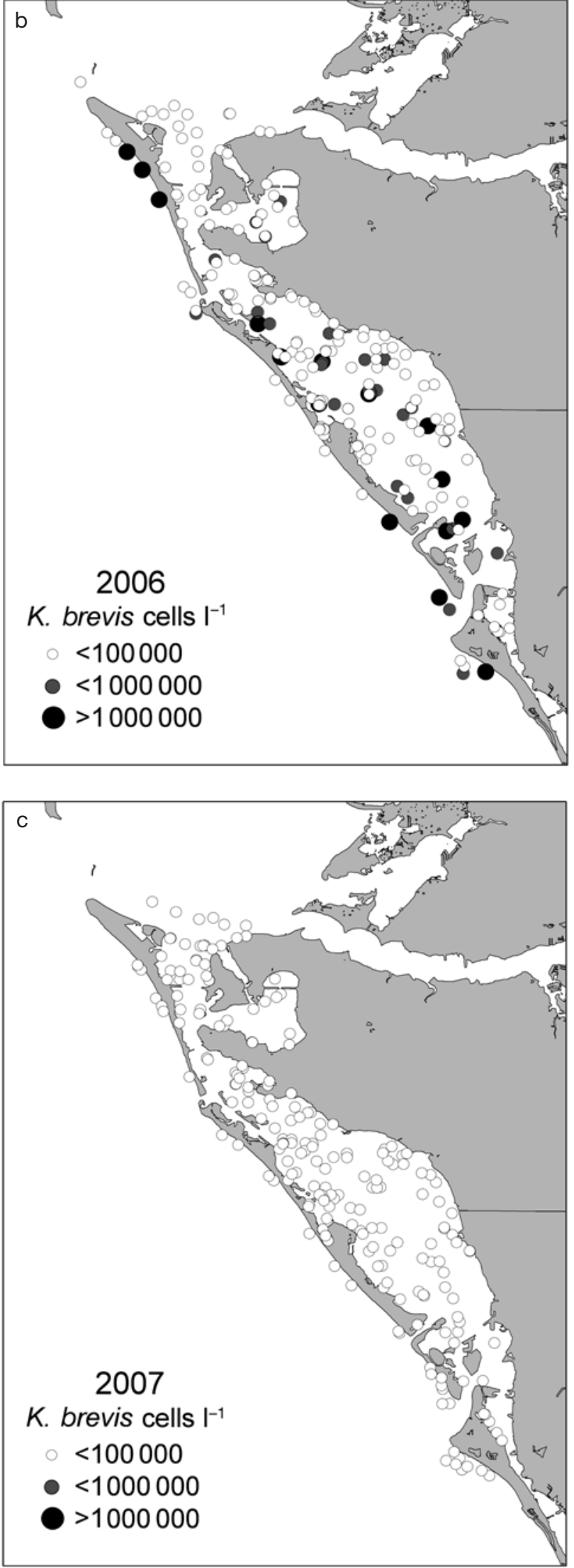
Table 2. Karenia brevis. Cell densities (mean and SD) measured in 5 different habitats during red-tide events in the summers of 2005 and $2006\left(F_{4,132}=7.0, p<0.01\right)$. K. brevis was not present in any water samples collected at fish sampling sites during non-red tide periods. n: number of samples

\begin{tabular}{|c|c|c|c|}
\hline \multirow[t]{2}{*}{ Habitat } & \multicolumn{2}{|c|}{ Cell density (cells $\mathrm{l}^{-1}$ ) } & \multirow[t]{2}{*}{$\mathrm{n}$} \\
\hline & Mean & SD & \\
\hline Open bay & 920571 & 1200501 & 28 \\
\hline Mangrove & 817852 & 1613785 & 27 \\
\hline Gulf & 3681938 & 15605184 & 32 \\
\hline Sandflat & 513826 & 922222 & 23 \\
\hline Seagrass & 1786517 & 6328356 & 27 \\
\hline All habitats & 1918852 & 7984628 & 137 \\
\hline
\end{tabular}

Fish abundance, diversity, and community structure

During the summers of 2004 to 2007, we captured 208762 fishes from 118 species in 477 purse-seine sets. There were 8 stations at which no fish were caught (3 Gulf, 2 mangrove, 2 open bay, and 1 seagrass), all of which were sampled during red-tide periods. Total CPUEs (all species combined) were significantly lower during red-tide periods than non-red tide periods in all habitats (Fig. 5a). When the contribution of clupeids to the overall catches were removed from the analysis, the differences in combined catch rates between red tide and non-red tide periods for the remaining species were even greater (Fig. 5b).

CART analyses showed that Karenia brevis density was the only environmental variable consistently associated with catch rates: it was negatively related to catch rates in every habitat, appeared to have a stronger relationship with catch rates when clupeids were excluded from the analysis, and was the only variable statistically associated (negatively) with the CPUE of non-clupeid fishes (Table 3). With regard to catch rates, critical values for $K$. brevis cell densities ranged from 1 to 138037 cells $l^{-1}$ (Table 3 ). Salinity was positively associated with overall catch rates in the Gulf and open-bay habitats. Dissolved oxygen was negatively associated with overall catch rate in the sandflat habitat (critical value $=5.4 \mathrm{mg} \mathrm{l}^{-1}$ ) and positively associated with overall catch rate (secondarily to $K$. brevis count) in the seagrass habitat (critical value $=$ $4.3 \mathrm{mg} \mathrm{l}^{-1}$ ).

There were significant differences between red tide and non-red tide periods with regard to the ShannonWiener diversity indices in every habitat (Table 4). In all but the mangrove habitat, the Shannon-Wiener index was lower during red tide than non-red tide conditions. Species richness was also significantly lower during red-tide periods than during non-red tide periods in every habitat. CART analysis indicated a strong negative association between Karenia brevis cell den- sity and fish species diversity in every habitat (Table 3). Critical values for $K$. brevis cell densities were far below $10^{5}$ cells $1^{-1}$ in 3 habitats (Gulf, open bay, and seagrass). In the mangrove fringe habitat, water depth was also positively related to species richness.

Demersal omnivores (Guild 3), consisting primarily of pinfish Lagodon rhomboides, and pelagic filter feeders (Guild 6, primarily clupeids) were the 2 dominant guilds. Demersal omnivores tended to be most common in the seagrass and mangrove habitats, whereas pelagic filter feeders were most abundant in the more open waters (Gulf, open bay, and sandflat; Table 5). MANOVAs of CPUEs for the 9 trophic guilds indicated significant differences in community structure between red tide and non-red tide periods for all 5 habitats (Tables 5 to 7 ). There was a general tendency for pelagic filter feeders to become more dominant during red-tide events as the abundance of other fishes decreased. Post hoc tests showed that the seagrass and Gulf habitats experienced the greatest changes in community structure, with 5 of 9 guilds exhibiting significant changes in abundance in the seagrass habitat and 4 out of 5 guilds changing significantly in the Gulf
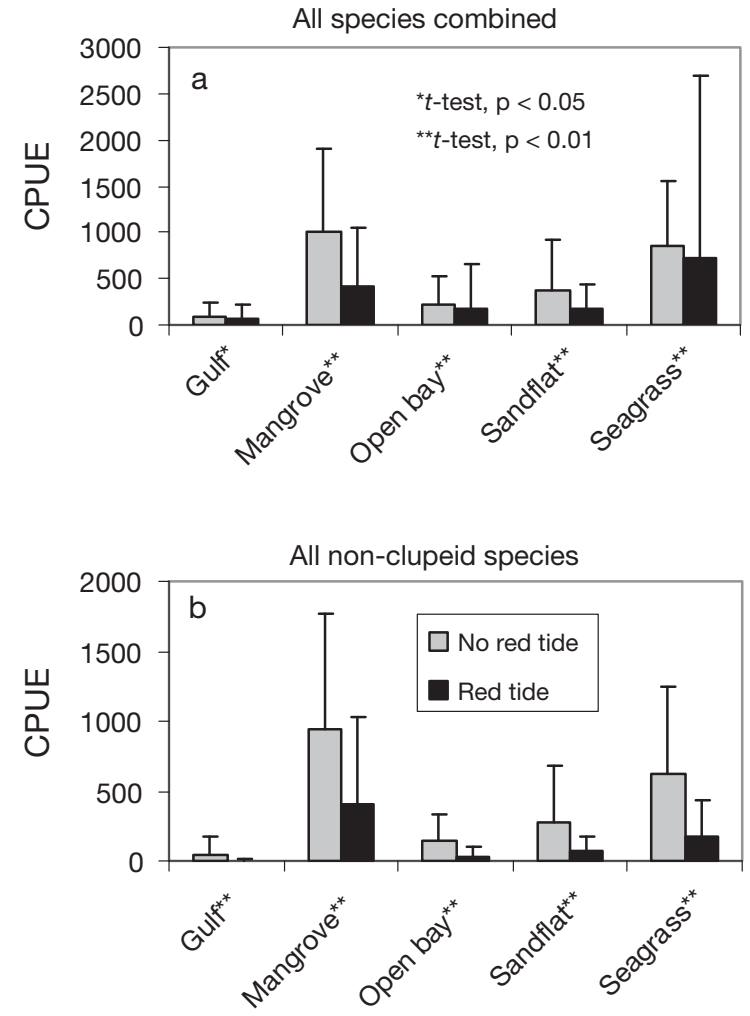

Fig. 5. Catch per unit effort (CPUE) of (a) all fish species and (b) all non-clupeid fish species during non-red tide and redtide periods in 5 habitats during the summers of 2004 to 2007. ${ }^{*} t$-test, $\mathrm{p}<0.05{ }^{* *} t$-test, $\mathrm{p}<0.01$ 
Table 3. Summary of classification and regression tree analyses (CART) for 3 dependent variables in each of 5 habitats. Three separate analyses were used to investigate how the independent (environmental) variables affect each of 3 dependent variables (Total CPUE: catch per unit effort [CPUE] of all fish species; CPUE - Clups: total CPUE minus the CPUE of clupeid fishes; Species: number of species caught per purse-seine set). The independent variables in each analysis run included dissolved oxygen (DO, $\left.\mathrm{mg} \mathrm{l}^{-1}\right)$, salinity (ppt), depth $(\mathrm{m})$, temperature $\left({ }^{\circ} \mathrm{C}\right)$, and Karenia brevis cell count (cells $\left.\mathrm{l}^{-1}\right)$. Secchi depth (m) was included in analyses of Gulf and open-bay habitats. Sig. var.: significant variable; Relationship: direction of the relationship (positive [Pos.] or negative [Neg.]) between the significant environmental variable and the dependent variable. $(-)$ model has only one significant variable

\begin{tabular}{|c|c|c|c|c|}
\hline Habitat (no. of samples) & Parameter & Total CPUE & $\begin{array}{l}\text { hdent variable } \\
\text { CPUE - Clups }\end{array}$ & Species \\
\hline Gulf $(\mathrm{n}=71)$ & $\begin{array}{l}\text { Sig. var. } 1 \\
\text { Critical value } \\
\text { p } \\
\text { Relationship }\end{array}$ & $\begin{array}{l}\text { Salinity } \\
34.4 \mathrm{ppt} \\
<0.04 \\
\text { Pos. }\end{array}$ & $\begin{array}{l}\text { K. brevis } \\
0 \text { cells } \mathrm{l}^{-1} \\
<0.02 \\
\text { Neg. }\end{array}$ & $\begin{array}{l}\text { K. brevis } \\
0{\text { cells } 1^{-1}}^{-1} \\
<0.02 \\
\text { Neg. }\end{array}$ \\
\hline Mangrove $(\mathrm{n}=67)$ & $\begin{array}{l}\text { Sig. var. } 1 \\
\text { Critical value } \\
\text { p } \\
\text { Relationship } \\
\text { Sig. var. } 2 \\
\text { Critical value } \\
\text { p } \\
\text { Relationship }\end{array}$ & $\begin{array}{l}\text { K. brevis } \\
138037 \text { cells } l^{-1} \\
<0.02 \\
\text { Neg. } \\
- \\
- \\
-\end{array}$ & $\begin{array}{l}\text { K. brevis } \\
138037 \text { cells }^{-1} \\
<0.02 \\
\text { Neg. } \\
- \\
- \\
-\end{array}$ & $\begin{array}{l}\text { K. brevis } \\
138037 \text { cells } \mathrm{l}^{-1} \\
<0.02 \\
\text { Neg. } \\
\text { Depth } \\
0.8 \mathrm{~m} \\
<0.02 \\
\text { Pos. }\end{array}$ \\
\hline Open bay $(\mathrm{n}=70)$ & $\begin{array}{l}\text { Sig. var. } 1 \\
\text { Critical value } \\
\text { p } \\
\text { Relationship }\end{array}$ & $\begin{array}{l}\text { Salinity } \\
32.6 \mathrm{ppt} \\
<0.02 \\
\text { Pos. }\end{array}$ & $\begin{array}{l}\text { K. brevis } \\
71943 \text { cells } 1^{-1} \\
<0.02 \\
\text { Neg. }\end{array}$ & $\begin{array}{l}\text { K. brevis } \\
999 \text { cells }^{-1} \\
<0.02 \\
\text { Neg. }\end{array}$ \\
\hline Sandflat $(\mathrm{n}=62)$ & $\begin{array}{l}\text { Sig. var. } 1 \\
\text { Critical value } \\
\text { p } \\
\text { Relationship }\end{array}$ & $\begin{array}{l}\text { DO } \\
5.4 \mathrm{mg} \mathrm{l}^{-1} \\
<0.02 \\
\text { Neg. }\end{array}$ & $\begin{array}{l}\text { K. brevis } \\
20988 \text { cells } 1^{-1} \\
<0.02 \\
\text { Neg. }\end{array}$ & $\begin{array}{l}\text { K. brevis } \\
87901 \text { cells }^{-1} \\
<0.02 \\
\text { Neg. }\end{array}$ \\
\hline Seagrass $(n=72)$ & $\begin{array}{l}\text { Sig. var. } 1 \\
\text { Critical value } \\
\text { p } \\
\text { Relationship } \\
\text { Sig. var. } 2 \\
\text { Critical value } \\
\text { p } \\
\text { Relationship }\end{array}$ & $\begin{array}{l}\text { K. brevis } \\
33035 \text { cells } \mathrm{l}^{-1} \\
<0.02 \\
\text { Neg. } \\
\text { DO } \\
4.3 \mathrm{mg} \mathrm{l}^{-1} \\
<0.05 \\
\text { Pos. }\end{array}$ & $\begin{array}{l}\text { K. brevis } \\
33035 \text { cells } 1^{-1} \\
<0.02 \\
\text { Neg. } \\
- \\
- \\
-\end{array}$ & $\begin{array}{l}\text { K. brevis } \\
30973 \text { cells }^{-1} \\
<0.02 \\
\text { Neg. } \\
- \\
- \\
-\end{array}$ \\
\hline
\end{tabular}

habitat. Community structure in the sandflat habitat changed the least of any habitat; only Guild 2 (demersal invertebrate feeders) exhibited a significant difference in abundance between red tide and non-red tide periods. Members of Guild 2 appeared to be the most sensitive to the effects of red tide, as their densities in every habitat were significantly lower during red-tide periods than they were during non-red tide periods. On the other hand, members of Guild 6 (clupeids) appeared to be least sensitive to red tide, as there was no significant difference in their abundance between red tide and non-red tide periods in any habitat.

CCAs showed that purse-seine catches in all 5 habitats generally clustered into 2 groups according to the relative abundance of each guild, and that these clusters corresponded with purse-seine samples taken during red tide and non-red tide periods, respectively (Fig. 6). The red tide and non-red tide samples segregated from each other along the Karenia brevis cell
Table 4. Species richness (mean number of species captured per purse-seine set) and Shannon-Wiener diversity index $\left(H^{\prime}\right)$ in 5 habitats and adjacent waters during red tide and non-red tide conditions. For each habitat: species richness: Student's

2 -sample $t$-test, $\mathrm{p}<0.05 ; H^{\prime}$ : Hutcheson's $t$-test, $\mathrm{p}<0.05$

\begin{tabular}{|c|c|c|c|c|}
\hline \multirow{2}{*}{ Habitat } & \multicolumn{2}{|c|}{ Non-red tide } & \multicolumn{2}{|l|}{ Red tide } \\
\hline & Species richness & $H^{\prime}$ & Species richness & $H^{\prime}$ \\
\hline Mangrove & 12.6 & 0.50 & 6.4 & 0.64 \\
\hline Gulf & 6.5 & 0.83 & 2.6 & 0.21 \\
\hline Open bay & 11.8 & 0.90 & 4.2 & 0.62 \\
\hline Sandflat & 11.8 & 0.86 & 6.1 & 0.74 \\
\hline Seagrass & 14.5 & 0.79 & 7.5 & 0.69 \\
\hline
\end{tabular}

count gradients. The $K$. brevis vectors terminated in the center of the clusters of points representing purseseine samples collected during red-tide conditions. In every habitat except mangrove, Guild 6 (pelagic filter feeders, including clupeids) was plotted within the 
Table 5. Catch per unit effort (CPUE, mean \pm SD) for 9 fish guilds in 5 habitats during red tide and non-red tide periods. Guild 1: demersal herbivore, 2: demersal invertivore; 3: demersal omnivore; 4: demersal piscivore; 5: detritivore; 6: pelagic filter feeder; 7: pelagic invertivore; 8: pelagic omnivore; 9: pelagic piscivore

\begin{tabular}{|c|c|c|c|c|c|c|c|c|c|c|}
\hline \multirow{2}{*}{$\begin{array}{r}\text { Guild } \\
1\end{array}$} & \multicolumn{2}{|c|}{$\begin{array}{l}\text { Mangrove } \\
\text { Non-red tide Red tide }\end{array}$} & \multicolumn{2}{|c|}{$\begin{array}{c}\text { Gulf } \\
\text { Non-red tide Red tide }\end{array}$} & \multicolumn{2}{|c|}{$\begin{array}{c}\text { Open bay } \\
\text { Non-red tide Red tide }\end{array}$} & \multicolumn{2}{|c|}{$\begin{array}{c}\text { Sandflat } \\
\text { Non-red tide Red tide }\end{array}$} & \multicolumn{2}{|c|}{$\begin{array}{c}\text { Seagrass } \\
\text { Non-red tide Red tide }\end{array}$} \\
\hline & $0 \pm 2$ & $0 \pm 0$ & $1 \pm 5$ & $0 \pm 0$ & $1 \pm 5$ & $0 \pm 1$ & $1 \pm 2$ & $0 \pm 0$ & $16 \pm 40$ & $0 \pm 0$ \\
\hline 2 & $110 \pm 108$ & $97 \pm 119$ & $9 \pm 15$ & $2 \pm 4$ & $55 \pm 90$ & $9 \pm 27$ & $100 \pm 200$ & $23 \pm 47$ & $116 \pm 142$ & $42 \pm 49$ \\
\hline 3 & $824 \pm 803$ & $300 \pm 495$ & $21 \pm 94$ & $1 \pm 3$ & $96 \pm 135$ & $23 \pm 47$ & $148 \pm 239$ & $35 \pm 70$ & $421 \pm 504$ & $79 \pm 114$ \\
\hline 4 & $19 \pm 16$ & $12 \pm 19$ & $10 \pm 11$ & $2 \pm 4$ & $21 \pm 19$ & $4 \pm 4$ & $29 \pm 29$ & $18 \pm 18$ & $21 \pm 25$ & $6 \pm 10$ \\
\hline 5 & $0 \pm 1$ & $0 \pm 1$ & $0 \pm 0$ & $0 \pm 0$ & $0 \pm 0$ & $0 \pm 0$ & $0 \pm 0$ & $0 \pm 0$ & $0 \pm 1$ & $0 \pm 0$ \\
\hline 6 & $109 \pm 334$ & $11 \pm 39$ & $24 \pm 52$ & $70 \pm 167$ & $103 \pm 203$ & $69 \pm 139$ & $121 \pm 431$ & $125 \pm 291$ & $188 \pm 367$ & $709 \pm 2281$ \\
\hline 7 & $3 \pm 13$ & $0 \pm 0$ & $0 \pm 2$ & $0 \pm 0$ & $0 \pm 0$ & $0 \pm 0$ & $0 \pm 0$ & $0 \pm 0$ & $0 \pm 0$ & $0 \pm 0$ \\
\hline 8 & $76 \pm 174$ & $83 \pm 201$ & $0 \pm 0$ & $0 \pm 0$ & $0 \pm 0$ & $0 \pm 0$ & $3 \pm 17$ & $0 \pm 2$ & $17 \pm 76$ & $2 \pm 10$ \\
\hline 9 & $1 \pm 1$ & $1 \pm 2$ & $8 \pm 15$ & $0 \pm 1$ & $4 \pm 11$ & $1 \pm 3$ & $7 \pm 27$ & $1 \pm 2$ & $4 \pm 9$ & $0 \pm 1$ \\
\hline
\end{tabular}

Table 6. Results of multivariate analyses of variance (MANOVAs) testing whether catches per unit effort of trophic guilds during non-red tide conditions differed from those of red tide conditions in each habitat of Sarasota Bay and adjacent waters. $\Lambda=$ Wilk's lambda, $\mathrm{R}=$ Rao's $\mathrm{R}$

\begin{tabular}{lccccc} 
Parameter & Mangrove & Gulf & $\begin{array}{c}\text { Open } \\
\text { bay }\end{array}$ & Sandflat & Seagrass \\
\hline$\Lambda$ & 0.72 & 0.57 & 0.56 & 0.77 & 0.54 \\
$\mathrm{R}$ & 2.92 & 12.1 & 12.9 & 4.07 & 7.29 \\
$\mathrm{df}$ & 9,69 & 5,80 & 5,82 & 5,67 & 9,78 \\
$\mathrm{p}$ & 0.01 & 0.01 & 0.01 & 0.01 & 0.01 \\
\hline
\end{tabular}

Table 7. p-values (significant values in bold) from Tukey's HSD post hoc test comparing the catch per unit effort for each guild during non-red tide conditions to those from red-tide conditions in each habitat. See Table 5 legend for guild descriptions. (-) guild present in $<10 \%$ of purse-seine samples for both red tide and non-red tide periods

\begin{tabular}{|lccccc|}
\hline Guild & Mangrove & Gulf & $\begin{array}{c}\text { Open } \\
\text { bay }\end{array}$ & Sandflat & Seagrass \\
\hline 1 & 0.35 & - & - & - & $\mathbf{0 . 0 1}$ \\
2 & $\mathbf{0 . 0 2}$ & $\mathbf{0 . 0 1}$ & $\mathbf{0 . 0 1}$ & $\mathbf{0 . 0 1}$ & $\mathbf{0 . 0 1}$ \\
3 & $\mathbf{0 . 0 1}$ & $\mathbf{0 . 0 2}$ & $\mathbf{0 . 0 1}$ & 0.09 & $\mathbf{0 . 0 1}$ \\
4 & $\mathbf{0 . 0 1}$ & $\mathbf{0 . 0 1}$ & $\mathbf{0 . 0 1}$ & 0.15 & $\mathbf{0 . 0 1}$ \\
5 & 0.57 & - & - & - & 0.57 \\
6 & 0.06 & 0.62 & 0.23 & 0.37 & 0.65 \\
7 & 0.17 & - & - & - & 0.57 \\
8 & 0.68 & - & - & - & 0.36 \\
9 & 0.37 & $\mathbf{0 . 0 1}$ & 0.07 & 0.08 & $\mathbf{0 . 0 2}$ \\
\hline
\end{tabular}

red-tide purse-seine sample cluster and near the terminus of the $K$. brevis vector. All other guilds in these 4 habitats were plotted within the cluster of non-red tide purse-seine samples. Eigenvalues were highest for the Gulf and lowest for the mangrove habitats (Table 8).
Table 8. Eigenvalues and total inertia for canonical correspondence analyses of fish community structure in 5 discrete habitats

\begin{tabular}{|c|c|c|c|c|}
\hline \multirow{2}{*}{ Habitat } & \multicolumn{3}{|c|}{ Eigenvalue } & \multirow{2}{*}{$\begin{array}{l}\text { Total } \\
\text { inertia }\end{array}$} \\
\hline & Axis 1 & Axis 2 & Axis 3 & \\
\hline Gulf & 0.133 & 0.064 & 0.010 & 0.758 \\
\hline Open bay & 0.062 & 0.017 & 0.007 & 0.509 \\
\hline Seagrass & 0.077 & 0.015 & 0.006 & 0.517 \\
\hline Mangrove & 0.027 & 0.013 & 0.005 & 0.320 \\
\hline Sandflat & 0.047 & 0.008 & 0.005 & 0.582 \\
\hline
\end{tabular}

\section{Fish kills}

In our study area, 131 fish kills were reported to Florida's fish kill database during the years 2003 to 2007. Of these fish kills, 126 (96\%) occurred on days when we classified the study area as being under redtide conditions. None of the 5 fish kills that occurred on days that we classified as being non-red tide were attributed to red tide in the state's database. The number of reported fish kills was lowest in 2007 ( $n=4)$ and highest in $2005(\mathrm{n}=72)$.

\section{DISCUSSION}

Three major red tides occurred in the study area between January 1, 2003 and December 31, 2007, with Karenia brevis densities peaking at over $10^{7}$ cells $\mathrm{l}^{-1}$. These red tides corresponded with massive fish kills, decreases in fish abundance and diversity, and changes in community structure in all 5 habitats sampled. Thus, the data were consistent with our 3 hypotheses regarding the effects of red tides on fish abundance, species diversity, and community structure. In addition to its impacts on fishes, the 2005 and 

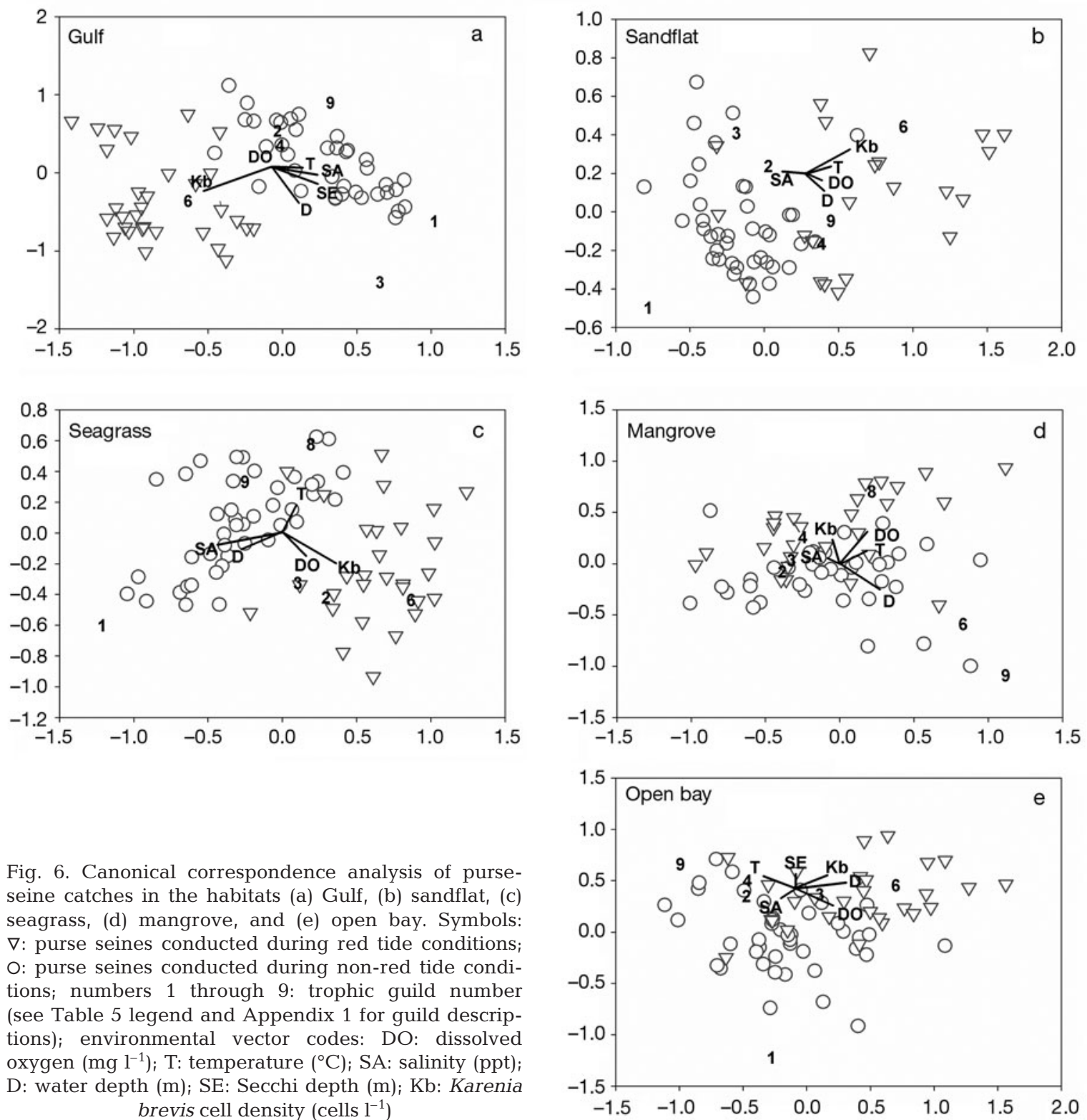

Fig. 6. Canonical correspondence analysis of purseseine catches in the habitats (a) Gulf, (b) sandflat, (c) seagrass, (d) mangrove, and (e) open bay. Symbols: $\nabla$ : purse seines conducted during red tide conditions; O: purse seines conducted during non-red tide conditions; numbers 1 through 9: trophic guild number (see Table 5 legend and Appendix 1 for guild descriptions); environmental vector codes: DO: dissolved oxygen $\left(\mathrm{mg} \mathrm{l}^{-1}\right)$; $\mathrm{T}$ : temperature $\left({ }^{\circ} \mathrm{C}\right)$; SA: salinity (ppt); D: water depth (m); SE: Secchi depth (m); Kb: Karenia brevis cell density (cells $\mathrm{l}^{-1}$ )

2006 Florida red tides prompted the National Marine Fisheries Service to formally declare a multispecies unusual mortality event for manatees Trichechus manatus latirostris, bottlenose dolphins Tursiops truncatus, and marine turtles along the central and southwest coast of Florida (NOAA 2006).

Many factors can affect reproduction, mortality, recruitment, and habitat use of fishes, so it can be difficult to identify the specific cause of a decline in fish abundance from observational field studies. However, the fact that nearly every species in all habitats showed the same pattern of changes in abundance (with the exception of clupeids) suggests a large-scale environmental perturbation was the underlying cause. The

overwhelming weight of evidence is consistent with the hypothesis that Karenia brevis red tides were a major causative factor contributing to the changes in fish abundance, diversity, and community structure.

Changes in total CPUEs between non-red tide and red-tide periods ranged from $-10 \%$ (seagrass) to $-60 \%$ (mangrove) (negative percentages indicating lower densities during red tide). However, when clupeids were excluded from the analysis, the changes in CPUE between non-red tide and red-tide periods ranged from $-57 \%$ (mangrove) to $-88 \%$ (Gulf). The largest absolute change in non-clupeid fish density occurred in the mangrove habitat. On average, 537 fewer nonclupeid fishes were caught per purse-seine set during 
red-tide periods in the mangroves, compared to nonred tide periods when 936 non-clupeid fish were caught per set on average.

Distinct differences were found between red tide and non-red tide periods regarding the structures of the fish communities (Tables 4 to 7, Fig. 6). In the CCAs, differentiation between the communities present during red tide and non-red tide conditions corresponded with the environmental vector representing Karenia brevis cell count (Fig. 6). Of all the factors measured (water temperature, dissolved oxygen concentration, salinity, turbidity, depth, and K. brevis density), only $K$. brevis density was associated with decreased fish-catch rates and with decreased species richness in every habitat (Table 3, Fig. 6). These results suggest that the changes in the fish community were directly related to the presence of $K$. brevis or to brevetoxins, rather than to phenomena secondarily caused by blooms, such as hypoxia.

Species richness during red-tide periods was significantly lower than during non-red tide periods in all habitats, and the Shannon-Wiener diversity index was significantly lower during red tides in all habitats except the mangrove fringe. The Shannon-Wiener index takes into account both species richness and evenness. Therefore, the higher Shannon-Wiener index value in the mangrove fringe habitat during red tides can be attributed to greater species evenness.

The numbers of fish kills increased during red tides. Ninety-six percent of fish kills occurred when the study area was classified as being under red-tide conditions, and all fish kills attributed to red tide in the database occurred during periods in which we classified the study areas as being under red-tide conditions. The fish kills associated with these red-tide events, especially those in 2005, were massive and likely involved millions of fishes (authors' pers. obs.). During the entire red-tide event of 2005, the town of Longboat Key, 1 of 5 municipalities bordering the study area, removed 121 tons of dead fish from its beaches and residential canals (Cooper 2005). Fishes collected from the Sarasota Bay study area during these red-tide periods had high brevetoxin concentrations in their tissues (Fire 2006, Fire et al. 2008).

The changes in fish abundance and community structure that we documented could have been caused by mortality and/or emigration. Our sampling methods were unable to discriminate between these 2 potential mechanisms. However, the occurrence of extremely large fish kills and high PbTx concentrations in fish tissues (Fire 2006, Fire et al. 2008) suggests brevetoxininduced mortality was a significant factor underlying the community-level changes. Brevetoxins are known to be lethal to fishes (Steidinger et al. 1973, Baden \& Mende 1982, reviewed by Landsberg 2002) and have also recently been demonstrated to accumulate in tissue of living specimens (Flewelling et al. 2005, Naar et al. 2007, Fire et al. 2008). Brevetoxins can be detected in fish tissues more than a year following red tides (Naar et al. 2007) and were found in fish tissues several months following these particular red-tide events in Sarasota Bay (Fire et al. 2008), indicating that they remain in the food web for substantial periods of time.

Our CART analyses suggested that changes in abundance of non-clupeid fishes and in species richness might have occurred at Karenia brevis cell densities much lower than $10^{5}$ cells l$^{-1}$ (Table 3 ), which is the threshold density generally considered to induce fish kills (Quick \& Henderson 1974, Landsberg \& Steidinger 1998). For example, K. brevis cell densities greater than zero were identified as being negatively associated with the CPUE of non-clupeids in the Gulf habitat (Table 3). This would suggest that either fish kills occurred at cell densities lower than the $10^{5}$ cells $\mathrm{l}^{-1}$ threshold or that fish detected and avoided lowdensity $K$. brevis blooms. If fishes were displaced within the study area, fish densities would have increased in remaining refuges, similar to the habitat compression response fishes show to hypoxia (Eby \& Crowder 2002, Eby et al. 2005). However, we found no evidence of habitat compression at the scale of our study. It is possible that fishes may have abandoned the study area entirely in search of regions that were less affected by red tide, but this seems unlikely because the spatial extent of these red tides far exceeded that of the study area (Hu et al. 2006), meaning they would have had to move hundreds of kilometers to escape the red tide. The hypothesis that fishes emigrated away from areas afflicted by red tide also assumes that they can detect and avoid $K$. brevis blooms or brevetoxin itself, which has not been demonstrated experimentally. Thus the hypothesis that the observed changes in fish abundance were caused by brevetoxin-induced mortality is supported by our data and by the published literature, whereas the alternative hypothesis that the changes resulted from fish emigrating to other areas has less support but cannot yet be ruled out as a possible mechanism. It should be noted that potential lags between bloom occurrence and sample collection call for caution to be exercised when interpreting the cell-count thresholds identified by the CART analyses.

There are 2 potential mechanisms by which fish can be exposed to $\mathrm{PbTx}$ : direct exposure to free toxins dissolved in the water (released by lysed cells) and exposure via the food web. Experiments with filter-feeding striped mullet Mugil cephalus indicated that the route of exposure, in addition to the form and concentration of $\mathrm{PbTx}$, is important in determining the lethality of PbTx to fishes (Naar et al. 2007). Free PbTx was more 
lethal than equivalent concentrations of the same forms of the toxin contained within intact Karenia brevis cells that were consumed by the mullet. We used $K$. brevis cell count as a proxy for PbTx exposure because of the difficulties involved in making accurate measurements of both free and intracellular PbTx levels in field samples. The unarmored $K$. brevis cells break open very easily, so the process of sample collection and preparation may cause the concentration of free $\mathrm{PbTx}$ to be overestimated and that of intracellular PbTx to be underestimated. Brevetoxin can persist in the environment for extended periods. Fire et al. (2008) discovered brevetoxins more than 2 mo following a $K$. brevis bloom and Naar et al. (2007) detected brevetoxins more than a year post-bloom. Thus, $K$. brevis cell count is a crude measure of a fish's potential exposure to $\mathrm{PbTx}$. A simple, rapid method of simultaneously assessing the concentrations of brevetoxins that are free in the water and contained within living $K$. brevis cells would undoubtedly improve our understanding of the relative importance of the major $\mathrm{PbTx}$ vectors. Despite these limitations, we were still able to detect relationships between $K$. brevis cell counts and fish abundance.

Due to their frequency and severity, Florida red tides are likely to have an important influence on the structural dynamics of estuarine and nearshore communities in this region. HABs in general appear to be increasing in frequency and severity in many regions of the world (Anderson 1989, Smayda 1990, Hallegraeff 1993, Van Dolah 2000). Karenia brevis red tides occur nearly every year in the Sarasota Bay region, and Brand \& Compton (2007) suggested that $K$. brevis blooms are increasing in frequency and severity in southwest Florida. Thus the influence of red tides on fish abundance, diversity, and species composition may be increasing.

One group of fishes, Guild 6 (clupeids), stands out from all others. Whereas the abundance of most guilds declined significantly during red tide, the abundance of clupeids did not (Tables $6 \& 7$, Figs. $5 \& 6$ ). The CCA results actually indicate an association between Karenia brevis density and the abundance of Guild 6 . These data suggest that clupeids may have been more tolerant of brevetoxin poisoning, were better able to metabolize brevetoxins than were other fishes, or were better able to detect and avoid patches of $K$. brevis or brevetoxin. Being able to cope with exposure to brevetoxin might allow clupeids to occupy areas or to consume food items that might not otherwise be suitable for them. Given the high mortality that we observed for most other fishes during red tides, clupeids may become a more substantial portion of the diet for piscivores, such as seabirds and bottlenose dolphins, during these disturbance events. Thus, clupeids are likely to be an important vector by which brevetoxins are transferred to upper trophic levels (Flewelling et al. 2005). During the 2005 red tide, bottlenose dolphins in the Sarasota region exhibited changes in behavior that were consistent with a dietary shift toward clupeids (J. Gannon et al. unpubl. data).

Our study differed from those of Smith $(1975,1979)$ and Warlen et al. (1998) in a number of ways. Smith $(1975,1979)$ studied the communities on patch reefs in the Gulf of Mexico, offshore from our study area. He recorded the presence and absence of fish species at each study site using visual (SCUBA) surveys, but did not quantify density or abundance. He estimated that $77 \%$ of resident fish species disappeared from reefs in the 12 to $18 \mathrm{~m}$ depth range and attributed most of the mortality to indirect (hypoxia) rather than to direct (brevetoxicosis) effects of the HAB. In contrast, we recorded just a $37 \%$ decrease in the overall number of fish species during red tides in the 5 habitats that we studied, and hypoxia did not appear to play a significant role in the disturbance. The differences may be related to differences in methodologies, habitat characteristics, fish species, or relative severities of the redtide events studied. Smith's study sites were in deeper waters than were the sites studied here, and were likely to be more susceptible to density stratification, which may have promoted formation of hypoxic zones. A large hypoxic zone formed offshore of our study area during the 2005 red tide (Hu et al. 2006) but it did not appear to affect our study area directly.

Warlen et al. (1998) investigated densities of fish larvae recruiting to an estuary during red tide and non-red tide conditions. The recruitment rates they recorded during the red-tide event were not particularly low, although 2 of the 9 species investigated experienced their 8 yr recruitment minima during this period (Warlen et al. 1998). All of the fishes they studied were estuarine-dependent species that spawn in the ocean. Thus larval densities inside the estuary were likely affected by many ecological and oceanographic processes. In addition, responses of larvae to PbTx may differ from those of post-larval fishes.

The present study is the first step in identifying how Karenia brevis red tides affect nearshore fish communities. Important questions remain to be answered regarding (1) the importance of temporal and spatial scales of blooms to the fish community's response, (2) the fitness consequences of red tide to individual fishes, (3) synergistic effects of red tide and other forms of perturbation (e.g. hypoxia), (4) differences among species regarding their responses to red tide, and (5) economic and resource-management implications of red tide to fisheries. Unfortunately, very few of these topics can be adequately addressed using laboratory experiments alone. Due to the time scales involved 
(months to years) and the complex interactions that occur in nature, it is necessary to employ long-term observational field methods to investigate how natural communities respond to environmental stressors. Thus to achieve an adequate understanding of how HABs affect food webs, funding agencies need to make longterm commitments to consistent and continuous observational and sampling studies of marine food webs.

Acknowledgements. This project was made possible by the collective efforts of many people with a wide variety of talents. L. Woods fabricated the hydraulic-powered net hauler. L. Fulford designed our purse-seine net and B. Fulford constructed it. We are indebted to the interns and volunteers who worked hard to help us collect data in the field. There are too many to list here but we are grateful to them all for their hard work and dedication. We thank NOAA's Fisheries Service (grant award no. NA16FL1355) for the primary funding for this project and for obtaining and rigging the RV 'Flip' for purse-seining work. Harbor Branch Oceanographic Institution's Protect Wild Dolphins Program (grant nos. PWD 200418 and PWD 2005-09), Florida's State Wildlife Grants Program (SWG05_028), and Florida's Fish and Wildlife Research Institute (FWCC grant no. 04089) provided additional funding for this work. This research was authorized by the Florida Fish and Wildlife Conservation Commission (Special Activity License nos. 03SR-809 and 04SR-809) and by Mote Marine Laboratory's Institutional Animal Care and Use Committee (protocol nos. 06-10-DG1 and 07-10-DG1).

\section{LITERATURE CITED}

Allen LG (1982) Seasonal abundance, composition, and productivity of the littoral zone assemblage in upper Newport Bay, California. Fish Bull (Wash DC) 80:769-790

Anderson DM (1989) Toxic algal blooms and red tides: a global perspective. In: Okaichi T, Anderson DM, Nemoto $\mathrm{T}$ (eds) Red tides: biology, environmental science and toxicology. Elsevier, New York, p 11-16

Baden DG, Mende TJ (1982) Toxicity of two toxins from the Florida red tide marine dinoflagellate, Ptychodiscus brevis. Toxicon 20:457-461

Brand LE, Compton A (2007) Long-term increase in Karenia brevis abundance along the southwest Florida coast. Harmful Algae 6:232-252

Cooper C (2005) Red tide costs stress LBK's budget plan. Longboat Key News, Oct. 28, 2005, p 1

Deegan LA, Thompson BA (1985) The ecology of fish communities in the Mississippi River deltaic plain. In: YáñezArancibia A (ed) Fish community ecology in estuaries and coastal lagoons: towards an ecosystem integration. UNAM Press, Mexico City, p 35-56

> Eby LA, Crowder LB (2002) Hypoxia-based habitat compression in the Neuse River estuary: context-dependent shifts in behavioral avoidance thresholds. Can J Fish Aquat Sci 59:952-965

Eby LA, Crowder LB, McClellan CM, Peterson CH, Powers MJ (2005) Habitat degradation from intermittent hypoxia: impacts on demersal fishes. Mar Ecol Prog Ser 291:249-262

Fire SE (2006) Effects of Karenia brevis blooms on wild coastal bottlenose dolphins (Tursiops truncatus) in Sarasota Bay, Florida. PhD dissertation, University of California, Santa Cruz, CA
Fire SE, Flewelling LJ, Naar J, Twiner MJ and others (2008) Prevalence of brevetoxins in prey fish of bottlenose dolphins in Sarasota Bay, Florida. Mar Ecol Prog Ser 368: 283-294

Flewelling LJ, Naar J, Abbott JP, Baden DG and others (2005) Brevetoxicosis: red tides and marine mammal mortalities. Nature 435:755-756

Guillard R (1973) Division rates. In: Stein J (ed) Phycological methods. Cambridge University Press, Cambridge, p 289-311

> Guisan A, Zimmermann NE (2000) Predictive habitat distribution models in ecology. Ecol Model 135:147-186

Gunter G, Williams RH, Davis CC, Smith FGW (1948) Catastrophic mass mortality of marine animals and coincident phytoplankton bloom on the west coast of Florida, November 1946 to August 1947. Ecol Monogr 18:309-324

Hallegraeff GM (1993) A review of harmful algal blooms and their apparent global increase. Phycologia 32:79-99

HARRNESS (2005) Harmful algal research and response: a national environmental science strategy 2005-2015. Ramsdell JS, Anderson DM, Gilbert PM (eds) Ecological Society of America, Washington, DC

> Heck KL Jr, Hays C, Orth RJ (2003) Critical evaluation of the nursery role hypothesis for seagrass meadows. Mar Ecol Prog Ser 253:123-136

Hoese HD, Moore RH (1998) Fishes of the Gulf of Mexico, Texas, Louisiana, and adjacent waters, 2nd edn. Texas A\&M University Press, College Station, TX

Hoss DE, Engel DW (1996) Environmental effects on fisheries. In: Vernberg FJ, Vernberg WB, Siewicki T (eds) Sustainable development in the southeastern coastal zone: environmental impacts on fisheries. University of South Carolina Press, Columbia, SC, p 171-186

> Hothorn T, Hornik K, Zeileis A (2006) Unbiased recursive partitioning: a conditional inference framework. J Comput Graph Statist 15:651-674

> Houde E, Rutherford E (1993) Recent trends in estuarine fisheries: predications of fish production and yield. Estuaries 16:161-176

Hu C, Muller-Karger FE, Swarzenski PW (2006) Hurricanes, submarine groundwater discharge, and Florida's red tides. Geophys Res Lett 33, L11601, doi:10.1029/ 2005GL025449

Hutcheson K (1970) A test for comparing diversities based on the Shannon formula. J Theor Biol 29:151-154

- Landsberg JH (2002) The effects of harmful algal blooms on aquatic organisms. Rev Fish Sci 10:113-390

Landsberg JH, Steidinger KA (1998) A historical review of Gymnodinium breve red tides implicated in mass mortalities of the manatee (Trichechus manatus latirostris) in Florida, USA. In: Reguera B, Blanco J, Fernandez ML, Wyatt T (eds) Harmful algae. Xunta de Galicia and Intergovernmental Oceanographic Commission, UNESCO, Paris, p 97-100

> Lund JWG, Kipling C, LeCren ED (1958) The inverted microscope method of estimating algal numbers and the statistical basis of estimations of counting. Hydrobiologia 11: $143-170$

McCune B, Grace JB (2002) Analysis of ecological communities. MjM Software, Gleneden Beach, OR

Naar JP, Flewelling LJ, Lenzi A, Abbott JP and others (2007) Brevetoxins, like ciguatoxins, are potent ichthyotoxic neurotoxins that accumulate in fish. Toxicon 50:707-723

NOAA (National Oceanographic and Atmospheric Administration) (2006) Notice; availability of new criteria for designation of marine mammal unusual mortality events (UMEs). Fed Regist 71:75234-75236 
Quick JA, Henderson GE (1974) Effects of Gymnodinium breve red tide on fishes and birds: a preliminary report on behavior, anatomy, hematology, and histopathology. In: Amborski R, Hood M, Miller R (eds) Proc Gulf Coast Reg Symp Dis Aquat Anim, Aug 16-17. Louisiana State University, Baton Rouge, LA, p 85-113

Robins CR, Ray GC, Douglass J (1999) Peterson field guides: Atlantic coast fishes. Houghton Mifflin, Boston, MA

Sellner KG, Doucette GJ, Kirkpatrick GJ (2003) Harmful algal blooms: causes, impacts, and detection. J Ind Microbiol Biotechnol 30:383-406

Shannon CE, Weaver W (1949) The mathematical theory of communication. University of Illinois Press, Urbana, IL

Smayda TJ (1990) Novel and nuisance phytoplankton bloom in the sea: evidence for a global epidemic. In: Granéli E, Sundstrom B, Edler L, Anderson DM (eds) Toxic marine phytoplankton. Elsevier, New York, p 29-40

Smith GB (1975) The 1971 red tide and its impact on certain reef communities in the eastern Gulf of Mexico. Environ Lett 9:141-152

Smith GB (1979) Relationship of eastern Gulf of Mexico reeffish communities to the species equilibrium theory of insular biogeography. J Biogeogr 6:49-61

Sournia A (1978) Phytoplankton manual. Monographs on oceanographic methodology, Vol 6. UNESCO, Paris
Steidinger KA, Burklew M, Ingle RM (1973) The effects of Gymnodinium breve toxin on estuarine animals. In: Martin DF, Padilla GM (eds) Marine pharmacognosy: action of marine toxins at the cellular level. Academic Press, New York, p 179-202

ter Braak CJF, Verdonschot PFM (1995) Canonical correspondence analysis and related multivariate methods in aquatic ecology. Aquat Sci 57:255-289

Tomas CR (ed) (1997) Identifying marine phytoplankton. Academic Press, San Diego, CA

Urban D, Goslee S, Pierce K, Lookingbill T (2002) Extending community ecology to landscapes. Ecoscience 9:200-212

Utermöhl H (1958) Zur Vervollkommnung der quantitativen Phytoplankton-Methodik. Mitt Int Ver Theor Angew Limnol 9:1-38

- Van Dolah FM (2000) Marine algal toxins: origins, health effects, and their increased occurrence. Environ Health Perspect 108(S1):133-141

Warlen SM, Tester PA, Colby DR (1998) Recruitment of larval fishes into a North Carolina estuary during a bloom of the red tide dinoflagellate, Gymnodinium breve. Bull Mar Sci 63:83-95

Wessel MR, Winner BL (2003) Using a modified purse seine to collect and monitor estuarine fishes. Gulf Caribb Res 15: $61-71$

Appendix 1. Membership of each trophic guild used in the analyses of community structure. Information on food habits and habitat selection, which was used to assign each species to a guild, was obtained from FishBase (www.fishbase.org/search.php, accessed on April 15, 2007), Hoese \& Moore (1998), and Robins et al. (1999), and references therein

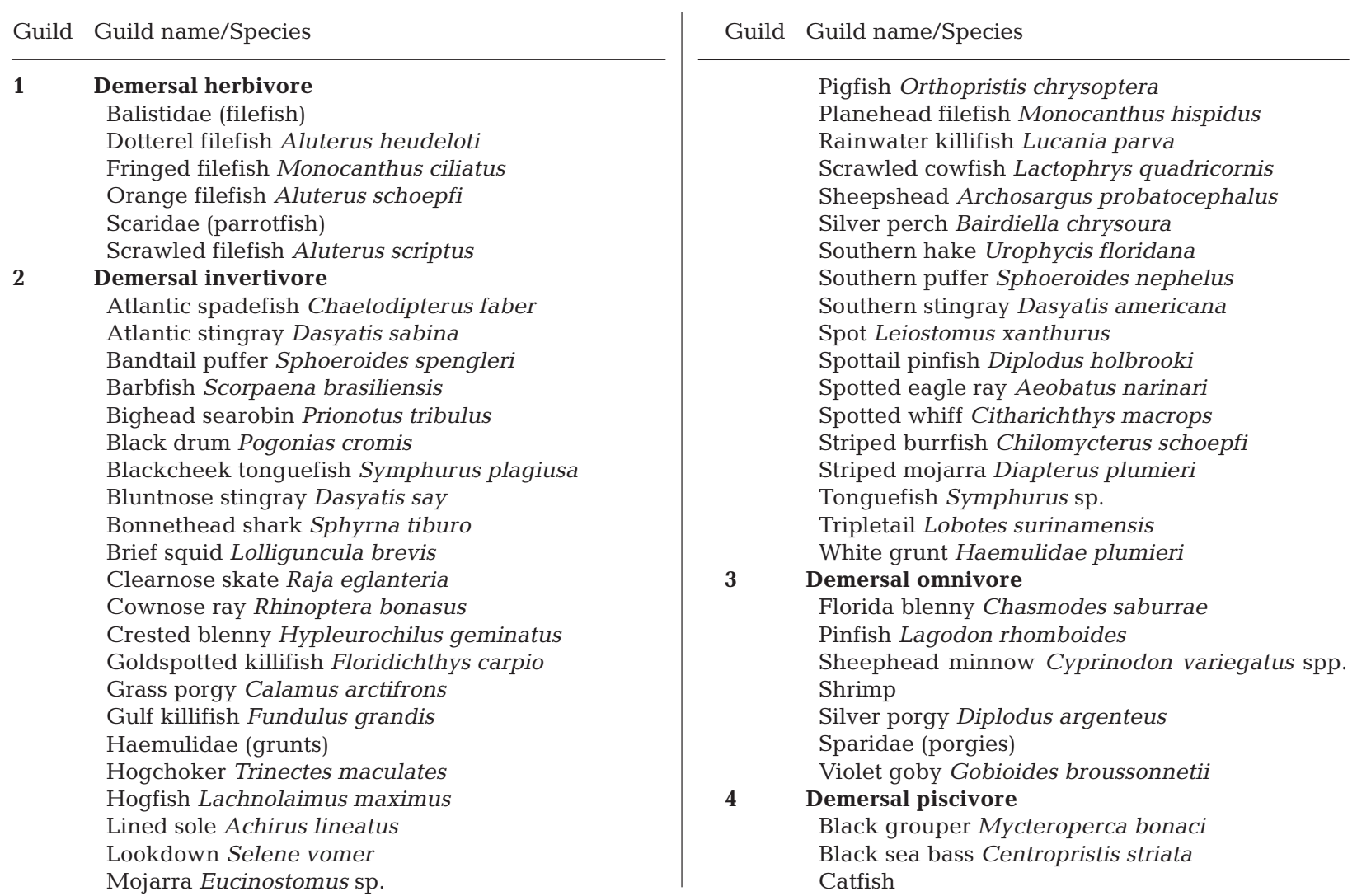


Appendix 1 (continued)

\begin{tabular}{|c|c|c|c|}
\hline Guild & Guild name/Species & Guild & Guild name/Species \\
\hline 4 & $\begin{array}{l}\text { Demersal piscivore (continued) } \\
\text { Common snook Centropomus undecimalis } \\
\text { Gafftopsail catfish Bagre marinus } \\
\text { Gag grouper Mycteroperca microlepis } \\
\text { Goliath grouper Epinephelus itajara } \\
\text { Gulf flounder Paralichthys albigutta } \\
\text { Gulf toadfish Opsanus beta } \\
\text { Hardhead catfish Arius felis } \\
\text { Inshore lizardfish Synodus foetens } \\
\text { Kingfish Menticirrhus sp. } \\
\text { Lane snapper Lutjanus synagris } \\
\text { Leopard searobin Prionotus scitulus } \\
\text { Loligo sp. } \\
\text { Longnose gar Lepisosteus osseus } \\
\text { Mangrove (gray) snapper Lutjanus griseus } \\
\text { Mutton snapper Lutjanus analis } \\
\text { Ocellated flounder Ancylopsetta quadrocellata } \\
\text { Red drum Sciaenops ocellatus } \\
\text { Sand perch Diplectrum formosum } \\
\text { Sand seatrout Cynoscion arenarius } \\
\text { Serranidae } \\
\text { Slender inshore squid Loligo plei } \\
\text { Smooth butterfly ray Gymnura micrura } \\
\text { Southern stargazer Astroscopus y-graecum } \\
\text { Spotted seatrout Cynoscion nebulosus } \\
\text { Yellowedge grouper Epinephelus flavolimbatus } \\
\text { Detritivore } \\
\text { Blackchin tilapia Tilapia melanotheron } \\
\text { Harvestfish Peprilus alepidotus } \\
\text { Pelagic filter feeder } \\
\text { Atlantic thread herring Opisthonema oglinum } \\
\text { Half beak Hyporhamphus unifasciatus } \\
\text { Menhaden Brevoortia spp. }\end{array}$ & 8 & $\begin{array}{l}\text { Rough silverside Membras martinica } \\
\text { Scaled sardine Harengula jaguana } \\
\text { Shad Alosa sp. } \\
\text { Spanish sardine Sardinella aurita } \\
\text { Striped anchovy Anchoa hepsetus } \\
\text { Yellowfin menhaden Brevoortia smithi } \\
\text { Clupeidae (herrings) } \\
\text { Pelagic invertivore } \\
\text { Fundulidae (killifish) } \\
\text { Gulf butterfish Peprilus burti } \\
\text { Inland/tidewater silverside Menidia spp. } \\
\text { Round scad Decapterus punctatus } \\
\text { Pelagic omnivore } \\
\text { Cyprinodontidae (killifish) } \\
\text { Fantail mullet Mugil gyrans } \\
\text { Striped (black) mullet Mugil cephalus } \\
\text { Pelagic piscivore } \\
\text { Atlantic bumper Chloroscombrus chrysurus } \\
\text { Atlantic needlefish Strongylura marina } \\
\text { Blacktip shark Carcharhinus limbatus } \\
\text { Blue runner Caranx crysos } \\
\text { Bluefish Pomatomus saltatrix } \\
\text { Carangidae (jack) } \\
\text { Cobia Rachycentron canadum } \\
\text { Crevalle jack Caranx hippos } \\
\text { Florida pompano Trachinotus carolinus } \\
\text { Ladyfish Elops saurus } \\
\text { Leatherjack Oligoplites saurus } \\
\text { Permit Trachinotus falcatus } \\
\text { Sharksucker Echeneis naucrates } \\
\text { Spanish mackerel Scomberomorus maculatus } \\
\text { Sphyraenidae (sennet) } \\
\text { Yellow jack Caranx bartholomali } \\
\text { Yellowtail snapper Ocyurus chrysurus }\end{array}$ \\
\hline
\end{tabular}

Editorial responsibility: Charles Peterson, Morehead City, North Carolina, USA
Submitted: May 15, 2008; Accepted: November 25, 2008 Proofs received from author(s): February 25, 2009 